\title{
The Role of Salatiga Police Community Development Unit in Preventing the Crime of Embezzlement of Rental Cars
}

\author{
Evita Isretno Israhadi ${ }^{1}$, Faisal Santiago ${ }^{2}$ \\ University of Borobudur ${ }^{1,2}$ \\ \{evita_isretno@borobudur.ac.id ${ }^{1}$, faisalsantiago@borobudur.ac.id $\left.^{2}\right\}$
}

\begin{abstract}
Community development unit of Salatiga Police in tackling the crime of embezzlement of rental cars. The approach used in this study is normativeempirical, namely legal research on the implementation or implementation of normative legal provisions in action on every particular legal event that occurs in society. The Salatiga Police Community Development Unit's role in Preventing the Crime of Embezzlement of Rental Cars seeks to overcome crimes through criminal law and prevention without criminal.
\end{abstract}

Keywords: Role of Community Development; Criminal Act; Rental Car Embezzlement

\section{Introduction}

The State of Indonesia is a country of law, as stated in the Constitution of the Republic of Indonesia year 1945 (NRI Constitution 1945), which regulates all aspects of Indonesian people's lives. There is stipulated firmly in the Explanation of the 1945 NRI Constitution that "the State of the Republic of Indonesia is based on the law (rechsstaat), not based on mere power (machstaat)". The law has an essential meaning in life aspects as a guideline for human behaviour concerning other human beings. In the State of law, the law is used to move every joint of public, national and state life. Also, the law is used as a means of social control so that the law exists to keep society in universally accepted patterns of behaviour. In this function, the law maintains what is and is taken in the community, but outside it, the law can still carry out its other parts by making changes in society. The law is tasked with integrating and coordinating the interests of each individual in the community. So it is expected that each other's interests can go hand in hand and not contradict each other. Achieving this goal can be done by limiting and protecting those interests.

Transportation is a means of transferring people or goods from one place to another using a vehicle driven by humans or machines. Transportation itself is divided into several kinds, seen from its sites such as land, sea and air transportation, judging by the public or private transportation. City transport cars and buses are considered alternatives to cheap driving options but have some drawbacks such as lower comfort and safety levels; therefore, many people are more interested in owning a private car. But not all people can afford to buy a personal vehicle for various reasons such as the high price of the car, the amount of 
maintenance costs of the four-wheeled vehicle, fuel oil price such as gasoline or diesel, and increases every year. Some people's inability to buy a private car is what entrepreneurs see as a considerable business opportunity, namely by opening a car rental business.

Car rental is a type of business providing car rental services based on an agreement between the renter and the car owner, where the car can be rented daily or according to the contract. In that agreement, there are binding terms and conditions for both parties. The car rental business is considered to have a considerable opportunity with a reasonably significant advantage as well. Most of the reasons customers rent a rental car, such as wanting to travel somewhere but do not have a vehicle, and a rental car is their choice.

Many cases of embezzlement of rental cars are usually caused by the ease of a person to be able to rent a car only with the capital of conditions that are relatively easy to meet such as a photocopy of KTP (Identity Card), photocopy of driver's license (driver's license), photo pass, photocopy of family card and photocopy of NPWP (Taxpayer Identification Number). The occurrence of criminal acts committed by tenants against rental goods belonging to the rental owner due to abuse of rights or abuse of trust where the crime of embezzlement is stipulated in the provisions of Article 372 of the Penal Code. Embezzlement is the act of taking someone else's property in part or in whole where the possession of the goods already exists in the perpetrator, but the mastery occurs legally. For example, the perpetrator's domination of an item occurs because the owner entrusts the goods. The knowledge of the perpetrator's interests occurs because of their duties or positions, such as the goods storage officer. The purpose of embezzlement is to have the goods or money in its possession which the goods/money belongs to someone else. In the embezzlement of this rental car, the owner and renter have come faceto-face, have known each other's identities, but when in the middle of the agreement, the renter deliberately flees and sells or transfers his rental car to a third party.

Crime in society develops along with society's development because crime is a product of culture, which needs to be addressed. There is given that the crime will not be lost by itself. On the contrary criminal cases are increasingly common, and the most dominant is the type of crime against property, especially embezzlement crimes. That crimes against the property will appear to be on the rise in developing countries. This increase is in line with economic development and growth.

Evil can be interpreted criminologically and juridically. Evil in the criminological sense is human actions that tarnish the basic norms of society. There is intended as an act of element that violates the rules that live and develop in the community. Juridical crimes are evil behaviour or evil deeds in the sense of criminal law means that the crime is formulated in the illegal regulations. Another word for this crime is a criminal act / criminal act/offence.

\section{Methodology}

The approach used in this study is normative-empirical, namely legal research on the application or implementation of normative legal provisions in action on every particular legal event that occurs in society (empirical facts). This type of research is descriptive, i.e. Descriptive research is one type of research whose purpose is to present a complete picture of social settings or intended for exploration and clarification of a phenomenon or social reality by describing some variables related to problems and units studied between the phenomena tested. 


\section{Result and Discussion}

\subsection{The Role of the Salatiga Police Community Development Unit in Preventing the Crime of Car Rental Embezzlement}

The theory of countermeasures used in this writing uses the approach of crime prevention efforts, namely through:

a. Application of criminal law (Criminal Law Application);

b. Prevention WithoutPunishment( Prevention Without Punishment);

c. Influencing crime and criminalization through the mass media.

Crackdown/eradication after the crime occurred by cracking down on the perpetrators of theft of motor vehicles with violence that causes the death toll based on applicable laws. While items 2 and 3 focus on preventive efforts (prevention/prevention) before crimes, another problem is the difference in perception between the police and other law enforcement in treating criminals. Police as the vanguard in the hunt for criminals oriented to the protection of victims of crime. The police do their best to maintain the public order security by covering up all forms of deviant behaviour that the community is fighting for, namely:

a) Repressive efforts (crackdown/eradication).

It is a framework for the impeachment directed towards the disclosure of all crimes that have occurred that are referred to as non-threats of force that are authorized according to the law. Usually, people do so because of economic insistence, environmental factors, and low education, thus giving rise to committing a crime. In this case, the government and the police play an essential role in tackling criminal acts in the community.

b) Preventive Efforts (prevention/ prevention).

It is a series of activities to prevent the natural occurrence of crimes that include regulation, guarding, and patrols. Because the goal is to prevent and reduce the possibility of unintended occurrence, general preventive measures are usually cheaper than the cost of tackling or reducing an event's impact.

Based on the results of the interview that conducted, in obtaining the results: The role of the Community Development Unit of Salatiga Police in tackling the crime of embezzlement of rental cars is to complete counselling and coaching to the community, especially rental car entrepreneurs to be more alert to the threat of embezzlement and can improve the safety of vehicles to reduce the risk of embezzlement. Countermeasures made by public order security are non-penal efforts or prevention efforts before the occurrence of criminal acts, namely:

a. Data collection on the rental car business

b. Raiding places that are often the site of embezzlement car limit

c. Counselling to the public, especially rental car entrepreneurs, to improve the safety of their vehicles by installing a global positioning system (gps), providing identification stickers so that cars are easily recognized in case of embezzlement, as well as rental car entrepreneurs to be selective in choosing consumers or in recruiting drivers.

\subsection{Constraints Faced by the Police Community Development Unit in Preventing the Crime of Car Rental Embezzlement}

Obstacles or obstacles faced by the Community Development Unit of Salatiga Police In Preventing The Crime of Embezzlement of Rental Cars in the Salatiga area are as follows:

a. The law enforcement factor, the lack of members of the community development unit itself, thus limiting the community development unit's wiggle room, with the limited 
number of members makes an ineffective movement that community development unit can do. The lack of understanding of community development unit members about the development of the era is still far behind compared to embezzlement's sophisticated perpetrators. The information owned is less effective in tackling the crime of embezzlement of rental cars.

b. Public Law Awareness Factor, with a lack of awareness of public law, is the possibility of criminal acts, especially the crime of embezzlement of rental cars. The public is less alert to embezzlement threat, and the lack of fear of embezzlement perpetrators of legal threats makes them dare to commit crimes of embezzlement.

c. Factors of facilities and infrastructure, with limited facilities to conduct counselling to limit community development unit's wiggle room. The little fund's available accommodation is also one of the inhibitory factors that are pretty felt.

Based on the results of interviews conducted against Sat Reskrim personnel in obtained results, the obstacles faced by the community development unit of Salatiga Police in preventing the crime of embezzlement of rental cars in the Salatiga area can be divided into two blocks, namely:

a) Internal barriers include :

Tidak sebandingnya jumlah personil polisi dengan luas wilayah yang perlu diawasi, Kurangnya data diri pihak kepolisian mengenai para pemilik mobil rental Susahnya mencari barang bukti.

b) External barriers include

1. Many people are still less responsive in reporting 1 X24 hours or not immediately report to the local police, so the car is out of reach, in addition to the report that is not directly or not immediately after the incident from the community and after deep identification was found no real series of acts of theft or embezzlement of the car.

2. Lack of cooperation with the open attitude of the car owner

3. The philosophy of car owners who tend to go to the police station if they feel lost for a long time

4. The proceeds of crime or stolen goods are sometimes not sold in full but sold in part. By not being sold in its entirety but sold in part, the perpetrators want to minimize being known by the police.

5. It is difficult to find evidence, because in general, the perpetrators sell proof to a remote area or far from the crime scene, so police officers are difficult to track it down.

\section{Conclusion}

The role of the Salatiga Police Community Development Unit in tackling the crime of embezzlement of rental cars is to conduct counselling and coaching to the community, especially rental car entrepreneurs, to be more alert to the threat of embezzlement and can improve the safety of their vehicles to reduce the risk of embezzlement. Countermeasures carried out by the community development unit are non-penal efforts or prevention efforts before the occurrence of criminal acts, namely data collection of rental car businesses and raiding places that are often the place of restriction of cars resulting from embezzlement counselling to the public, especially rental car entrepreneurs to improve the safety of their vehicles by installing a Global Positioning System (GPS), providing identification stickers so that cars are easily recognized in case of embezzlement, as well as rental car entrepreneurs to be selective in choosing consumers or in recruiting drivers. 
Factors inhibiting the role of the Salatiga Police Community Development Unit in tackling the crime of embezzlement of rental cars are:

a. The law enforcement factor, the lack of community development unit members, limits the community development unit's wiggle room, with the limited number of members making an ineffective movement that the community development unit can do. The lack of understanding of community development unit members about the development of the era is still far behind compared to embezzlement's sophisticated perpetrators. The information owned is less effective in tackling the occurrence of criminal embezzlement of rental cars.

b. Public Law Awareness Factor, with a lack of awareness of public law, is the possibility of criminal acts, especially the crime of embezzlement of rental cars. The public is less alert to embezzlement threat, and the lack of fear of embezzlement perpetrators of legal threats makes them dare to commit criminal acts of embezzlement.

c. Factors of facilities and infrastructure, with limited facilities to conduct counselling to limit community development unit's wiggle room. Limited funds for accommodation available are also one of the inhibitory factors that are pretty felt.

\section{References}

[1] Anwar, N. S. (2019). Analisis Transaksi Digital Cryptocurrency Sebagai Investasi Global Dalam Perspektif Hukum Islam (Studi Kasus Dinar Dirham di Makassar).

[2] Gordon, J. M. (1998). Business Law: An Introduction. Business Law: An Introductionby TheBusiness Professor.Com, 501(c), 428-431.

[3] Santiago, F. (2016). Bunga Rampai Catatan Hukum. Perpustakaan Nasional RI. Katalog Dalam Terbitan.

[4] Supriyanto, Eko Eddya. 2020. Eksistensi Nilai-Nilai Pancasila Dalam Kebijakan Ekonomi Indonesia. 1st ed. Malang: Literasi Nusantara.

[5] Supriyanto, E. E. (2021). Strategi Penerapan Kebijakan Sovereign Wealth Funds (SWFs) di Indonesia: Studi Literatur dan Studi Komparatif Oman. Jurnal Inovasi Ilmu Sosial Dan Politik (JISoP), 3(1), 10-21. https://doi.org/10.33474/jisop.v3i1.6959

[6] Nababan, K. N. N. (2019). Tinjauan Legalitas Transaksi Bitcoin di Indonesia. JuristDiction, 2(5), 1745-1764. 